УДК 338.45:338.24

DOI: https://doi.org/10.37320/2415-3583/7.4

Скоробогатова Н.С.

кандидат економічних наук, доцент, доцент кафедри міжнародної економіки

Національний технічний університет Украйни

«Київський політехнічний інститут імені Ігоря Сікорського»

Кравчук Ю.Г.

студент факультету менеджменту та маркетингу,

Національний технічний університет України

«Київський політехнічний інститут імені Ігоря Сікорського»

\title{
ГОТОВНІСТЬ УКРАЇНИ ДО ВПРОВАДЖЕННЯ НОВІТНІХ ТЕХНОЛОГІЙ ІНДУСТРІЇ 4.0
}

\begin{abstract}
У статті розкрито сутність та поняття новітнього тренду розвитку Індустрія 4.0, визначено дев'ять основних напрямів розвитку Четвертої промислової револючії. Доведено, щуо основою Індустрії 4.0 є інформаційно-комунікаційні технології, рушійною силою яких є IT-сфера. Проаналізовано сучасний стан розвитку IT-сфери в Украӥні, окресленого головні показники, побудовані тренди. Визначено місие Украйни в рейтингу Global Services Location Index. На основі проведеного дослідження зроблено висновок, щяо Украйна має високий потениіал у розробленні та впровадженні новітніх технологій Індустрії 4.0. Надано практичні рекомендації щзодо подальших кроків для ефективного входження України у коло світових новаторів Індустрії 4.0. Зокрема, визначено необхідність вжиття таких заходів, як розроблення стратегії регіонального розвитку промисловості з урахуванням наявних ресурсів та потенціалу розвитку міжнародної конкурентоспроможності; державна підтримка створення відповідних інноваційних осередків у вищих навчальних закладах; сприяння поширенню технологічних інновацій Індустрії 4.0 у депресивних регіонах; популяризаџія можливостей та переваг технологій Індустрії 4.0 у провідних інновачійних регіонах; розроблення нової політики кіберзахисту персональних даних.
\end{abstract}

Ключові слова: новітні технологї, інноваційний розвиток, Індустрія 4.0, інформаційно-комунікаційні технології, міжнародна конкурентоспроможність.

Постановка проблеми. Світ змінюється дуже швидкими темпами, і це не дивно, адже кожного дня людство винаходить нові технології та можливості їх застосування. Сучасні інформаційнокомунікативні засоби та технології $€$ рушійною силою не тільки науково-технічного прогресу, як це було раніше, але й світової економіки, що впливає як на бізнес, так і на життя людства загалом. Особливо величезних змін набуває інформація, адже саме вона $є$ основним ресурсом майбутнього. Передача даних, оброблення, аналіз, зберігання, управління - всі ці сфери набувають змін кожної години. Водночас впровадження новітніх технологій змінює самі економічні системи, створює нові напрями. Зараз усе частіше можна почути такі терміни, як «інформаційна економіка», «нова економіка», «економіка інновацій», «цифрова економіка», «економіка знань». Якщо проаналізувати напрями змін економічних систем, можна простежити закономірність: відбуваються кардинальні зміни бізнес-процесів, механізму управління конкурентоспроможними підприємствами, що потребує аудиту наявних можливостей та визначення перспектив подальшого розвитку.

Аналіз останніх досліджень i публікацій. Вперше світ дізнався про вектор розвитку «Індустрія 4.0» у квітні 2011 року. Вона була представлена на Ганноверській промисловій виставці-ярмарку трьома іiі першовідкривачами
Х. Кагерманном, В.-Д. Лукасом, В. Вальстером [6]. Проте вже за 5 років, а саме у січні 2016 року, Індустрія 4.0 стала основною темою 46-го Всесвітнього економічного форуму (World Economic Forum) у Давосі. Сьогодні вона поширюється в Україні серед науковців та практиків завдяки активній діяльності Асоціації підприємств промислової автоматизації України [8], науковців КПІ ім. Ігоря Сікорського [14] та інших закладів вищої освіти. Зарубіжні вчені присвятили цьому напряму багато досліджень, зокрема німецькі вчені Х. Кагерманн, В.-Д. Лукас, В. Вальстер досліджували Індустрію 4.0 з точки зору фактору підвищення конкурентоспроможності держави [6]; М. Рюсман, М. Лоренц, Ф. Герберт, М. Вальднер, Я. Юстус, П. Енгель, М. Харніш $[2 ; 4]$ аналізували тенденції розвитку Індустрії 4.0 та виокремили 9 найголовніших напрямів технічного прогресу. Джей Лі [5] активно досліджував у своїх працях особливості Індустрії 4.0 та іiї вплив на людство. А. Беспалов [1] розглядав зміни саме у промисловому виробництві, які несуть за собою новітні технології. Проте потребують подальшого дослідження визначення заходів підвищення ефективності використання інструментів Індустрії 4.0 в українській економіці.

Мета статті полягає в аналізі теоретичних та концептуальних засад Індустрії 4.0, дослідженні iii виникнення та розвитку, окресленні сучас- 
ного стану України в цьому світовому тренді та визначенні заходів щодо підвищення ефективності впровадження інноваційних технологій Індустрії 4.0.

Виклад основного матеріалу. Сутність концепції Індустрії 4.0 під час ії̈ презентації у Ганновері зосереджувалася на впровадженні новітніх технологій у промисловості та підключенні цих компонентів до величезної мережі обміну даними. Під час Третьої промислової революції світ спостерігав за впровадженням IКТ у різні сфери діяльності, автоматизацією виробництва, але Індустрія 4.0 має на меті не тільки поглиблення цього процесу, але й створення об'єднаної мережі. Вона передбачає об'єднання ресурсів, інформаційних потоків та об'єктів, а також людства загалом. Сенсом цього $є$ залучення людини до Всесвітньої мережі Індустріального Інтернету, або Інтернету речей. Цей вектор руху надалі впроваджують інші високорозвинені країни, зокрема США, Китай, Японія, Великобританія, Франція. Незважаючи на те, що про Індустрію 4.0 знають та говорять по всьому світі вже близько 10 років, для України цей рух все ще відбувається порівняно повільно. Відволікання в активному запровадженні базових положень концепції Індустрії 4.0 спонукає ризик залишитись аутсайдером світової арени, адже це $€$ трендом, якому слідує більшість країн світу або принаймні намагається слідувати.

Незважаючи на те, що Індустрія 4.0 - це відносно нове поняття, напрям, вона вже встигла набути популярності серед науковців. Вже сьогодні існує значна кількість тлумачень цього поняття. Всі вони $є$ однаковими, за винятком деталізації трактування складових частин цього терміна. Проаналізувавши підходи до визначення поняття Індустрія $4.0[2 ; 3 ; 4 ; 6]$, можемо стверджувати, що синонімами цього поняття користувачі вважають такі, як «Інтернет речей», «Четверта промислова революція», «Промисловий Інтернет речей». Також дослідження показало, що для кращого тлумачення використовуються такі терміни, як «кіберфізична система», «штучний інтелект», «промислове виробництво», «інтелектуальне виробництво», «самокерованість» [1;2]. Проте вважаємо, що ці трактування лише уточнюють складові елементи цього поняття, а не визначають його сутність. Окрім того, первісно під Індустрією 4.0 передбачалося застосування інформаційних технологій саме у сфері виробництва, а вже потім через використання терміна «Четверта промислова революція» воно поширилось на інші сфери діяльності.

Група німецьких дослідників, а саме М. Руссман, М. Лоренц, М. Герберт, П. Вальднер, М. Юстус, Дж. Енгел та П. Харніш [2; 4], визначили дев'ять розробок, які склали основу Четвертої промислової революції.
1) Big Data and Analytics. 3 кожною хвилиною кількість інформації невпинно зростає, але чіткої структури для неї, на жаль, ще немає. Саме через це часто підприємці зіштовхуються з такою проблемою, як оперативне здобуття інформації, необхідної для прийняття ефективних управлінських рішень. Пошук та подальша обробка інформації дістали назву “Big Data”. Огляд літературних джерел показав, що якщо пошук та збирання інформації - зараз уже більш-менш налагоджені процеси, то інтелектуальний аналіз (Data Mining) залишається актуальним питанням.

2) Autonomous Robots. Робототехніка була та залишається перспективним напрямом руху технологій. Щодо автономних роботів, то, як видно 3 назви, це роботи, які не потребують втручання людини в якийсь певний процес, здійснюваний роботом. Вони можуть бути певним устаткуванням у виробництві, що значно полегшує контроль та процес оптимізації виробництва.

3) Simulation або моделювання. Цю складову частину застосовують на етапах проєктування для кращої візуалізації бізнес-процесів. Слід зазначити, що в подальшому його планують застосовувати також безпосередньо у тестуванні, наприклад устаткування на виробництві. За допомогою віртуального представлення можна буде виявити ту чи іншу помилку ще на етапі тестування, що заощадить фінансові та часові ресурси підприємства.

4) Horizontal and Vertical System Integration. Ці процеси необхідні для створення єдиної інформаційної системи. Сьогодні, на жаль, інформаційний простір існує лише в рамках одного певного підприємства або логістичного ланцюга. Водночас зараз спостерігається жорстка ієрархічна система щодо доступу до інформації на підприємствах. Індустрія 4.0 прагне стерти ці рамки та надати доступ до всієї інформації незалежно від рівня.

5) The Industrial Internet of Things. Промисловий Інтернет речей є однією 3 найголовніших складових частин Четвертої промислової революції. Саме завдяки цій технології будуть поєднані всі компоненти виробництва у єдину цілісну мережу обміну інформацією в режимі реального часу.

6) Cybersecurity. 3 появою більшої кількості інформації, точніше, з повним іiі переходом до режиму "online" збільшиться кількість спроб нелегального отримання інформації. Це вже сьогодні є однією з проблем багатьох провідних компаній, коли вдається повною мірою захистити персональні дані користувачів, і через це виникає низка скандалів та судових процесів. Після впровадження Індустрії 4.0 кількість таких атак буде невпинно зростати, потрібно буде знаходити все новіші та більш досконаліші організаційні заходи кібербезпеки. 
7) The Cloud. Хмарні технології є вже сьогодні, проте суспільство не є обізнаними щодо них, тому не використовує їх повною мірою. 3 кожним роком інформація, яка генерується пристроями, постійно збільшується, звісно, вона має десь зберігатись. Продуктивність цих технологій лише зростає, однак уже зараз забезпечує постійний доступ до інформації.

8) Additive Manufacturing. Це стосується використання 3D-принтерів. Вже зараз є багато замовлень готової продукції з використанням цієї технології, яка одночасно допомагає економити витрати на складування та перевезення, адже підприємство самостійно може створювати невеликі партії, які їм необхідні на даний момент часу.

9) Augmented Reality. Розширена, або віртуальна, реальність дасть змогу швидше навчитися та прийняти те чи інше рішення. Наприклад, якщо певне устаткування на виробництві вийшло 3 ладу, а працівник, який одягнув окуляри віртуальної реальності, підійшов до нього. На екрані він побачить устаткування в теперішньому часі, йому надаються інструкція та можливі варіанти уникнення поломки.

Вищенаведені дев'ять елементів складають основу Індустрії 4.0 [2; 3; 4]. Як ми бачимо, вони $\epsilon$ виключно інформаційними засобами та технологіями.

Щодо України, то IT-сектор зараз має пріоритетне значення в економіці, демонструючи стійку тенденцію до зростання (рис. 1).

Сьогодні в Україні діє понад 1000 IT-компаній та існує близько 100 науково-дослідних центрів. Також IT в Україні набуває популярності, осо- бливо серед молоді. Як засвідчують статистичні дані, протягом останніх двох років спостерігається тенденція щодо зростання кількості зайнятих в IT в середньому на 30\% щороку. Динаміка чисельності зайнятих у цій сфері працівників наведена на рис. 2.

Також варто зазначити, що Україна займає досить хорошу позицію у рейтингу Global Services Location Index. Цей індекс щорічно обчислює та публікує консалтингова фірма “А.T. Kearney”. Цей рейтинг охоплює 55 найбільш перспективних економік щодо ведення бізнесу у сфері послуг. Значення цього показника для України наведене в табл. 1.

Таблиця 1 - Динаміка позиції України в рейтингу Global Services Location Index [12]

\begin{tabular}{|c|c|}
\hline Рік & $\begin{array}{c}\text { Місце в рейтингу Global Services } \\
\text { Location Index }\end{array}$ \\
\hline 2015 & 24 \\
\hline 2016 & 24 \\
\hline 2017 & 20 \\
\hline 2018 & 20 \\
\hline
\end{tabular}

Цей Індекс має три складові частини, такі як фінансова привабливість, навички та доступність людських ресурсів, бізнес-середовище. Як видно 3 табл. 1, Україна піднімає свої позиції у цьому рейтингу. Це пов'язане з тим, що кількість компаній, які працюють на засадах аутсорсингу, активно збільшує кількість своїх філій на території країни. Також це пояснюється значною кількістю висококваліфікованих працівників, їх доступністю та сприятливим бізнес-середовищем для роботи.

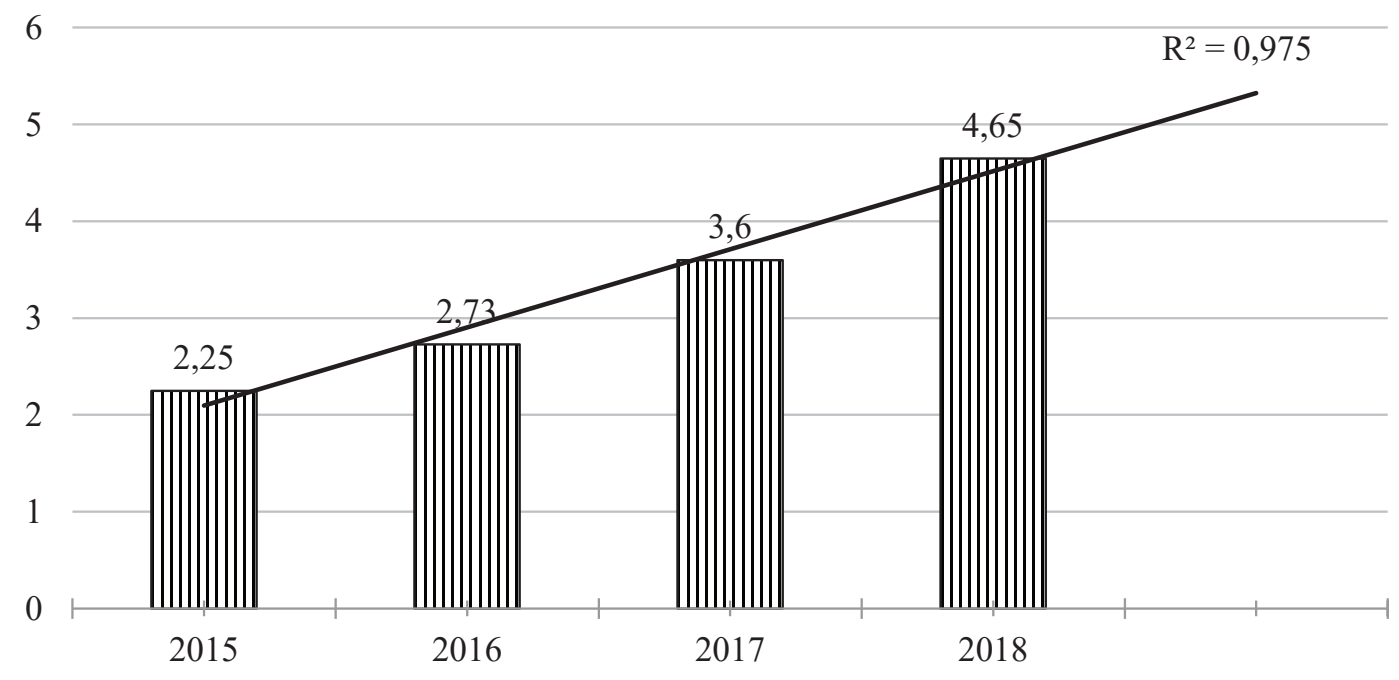

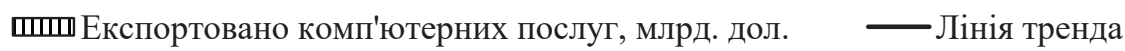

Рисунок 1 - Динаміка експорту комп'ютерних послуг України, 2015-2018 роки, млрд. дол. 


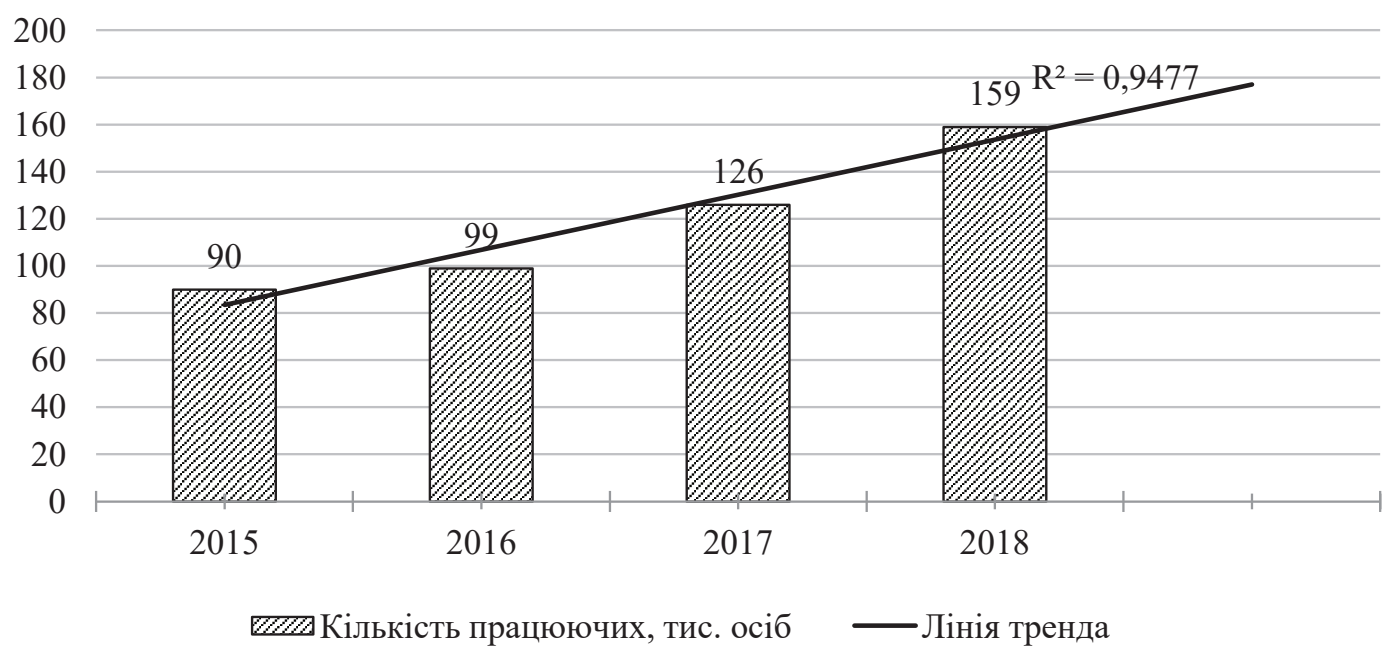
Рисунок 2 - Динаміка чисельності кількості зайнятих в IT-секторі,
2015-2018 роки, тис. осіб

Джерело: побудовано за даними джерела [6]

Якщо розглядати слабкі позиції, то для України нею $є$ фінансова привабливість, оскільки через нестабільну політичну та економічну ситуації інвестори мають острах щодо надійності та захищеності своїх вкладень.

Загалом українські інженери мають високий попит на зарубіжних ринках праці. Розглянувши останній рейтинг найкращих аутсорсерів світу, який складає "International Association of Outsourcing Professionals", із топ-100 провідних компаній кожна 10 має представництво в Україні. На думку експертів, близько 90\% усіх фахівців України тим чи іншим чином працюють на умовах аутсорсингу, отже, замість того, щоби розвивати вітчизняний IT-сектор, займатися реалізацією власних продуктів, фахівці віддають свої ідеї та технології за кордон.

Українські фахівці вже зарекомендували себе як найбільш соціально відповідальні. Продукцією, виготовленою українськими провайдерами, задоволені 94\% клієнтів. Це високий показник, оскільки в середньому іноземні компанії мають лише $84 \%$. Також про високий рівень креативності та кваліфікованості може свідчити те, що близько $72 \%$ усіх українських спеціалістів працюють у сфері інновацій. Україна посідає перше місце у Східній Європі за співвідношенням «ціна - якість», таку статистику надала консалтингова компанія “Gartner" [7].

Згідно з прогнозами експертів кількість зайнятих у 2020 році становитиме близько 240 тис. осіб. Такі тренди та прогнози свідчать про те, що IT-сектор $є$ динамічним, прогресивним та престижним сектором [7].

Отже, проаналізувавши різні аспекти IT-сектору України, можемо стверджувати, що впровадження новітніх технологій, які несе Інду- стрія 4.0, матиме не тільки економічний ефект, але й соціальний.

На основі аналізу аналітичної інформації $[1 ; 5$; $6 ; 9 ; 11]$ та наявних наукових джерел інформації можемо сказати, що задля ефективного поширення інноваційних рішень Четвертої промислової революції доцільно вжити таких заходів.

1) Розроблення стратегії регіонального розвитку промисловості 3 урахуванням наявного потенціалу для підвищення міжнародної конкурентоспроможності в умовах Індустрії 4.0, тобто необхідно визначити пріоритетні регіони та сектори економіки для розвитку технологій Індустрії 4.0 та активізувати співпрацю 3 приватним сектором в рамках цієї стратегії. Саме це буде рушійною силою модернізації промислового сектору. Особливо це актуально для регіонів, які створюють 15-20\% ВВП країни. Такий стратегічний підхід уже активно застосовують деякі країни Європи, зокрема Німеччина, Іспанія, Бельгія. Ініціатива "Vanguard", яка бере свій початок у 2013 році, сьогодні включає 30 таких регіонів, які активно розвиваються та зростають за допомогою «розумної спеціалізації». Сьогодні зазначена ініціатива активно підтримує 5 проєктів, які є близькими до ринкової промисловості. Їх співпраця діє в таких напрямах, як розширене виробництво для використання енергії в жорстких середовищах (ADMA Energy), біо-економіка, міжрегіональна співробітництво в галузі інноваційного використання непродовольчої біомаси, ефективне та стале виробництво (ESM), високоефективне виробництво за допомогою 3D-друку та нові експериментальні продукти з нанотехнологіями.

2) Державна підтримка створення відповідних інноваційних осередків у вищих навчальних закладах, тобто створення своєрідного середо- 
вища для розвитку та розширення обізнаності студентів 3 цифровими технологіями майбутнього. За допомогою цього середовища Індустрія 4.0 буде набувати більшої популярності серед молоді, оскільки вони будуть працювати 3 реальними кейсами за новітніми технологіями, отримувати цінний досвід від провідних фахівців, а головне, бачитимуть перспективи у цьому напрямі. Це буде однією 3 платформ запусків стартапів, що продуковані студентами.

3) Сприяння поширенню технологічних інновацій Індустрії 4.0 у депресивних регіонах. Широко використовуваною $\epsilon$ практика, коли високорозвинені регіони підтримували, мотивували та фінансували більш відсталі, депресивні регіони. Якщо розглядати це в рамках однієї країни, то це створюється задля балансу регіонів, щоби рівень життя населення був більш-менш рівномірним на теренах усієї держави. За допомогою цієї стратегії можна спонукати до впроваджень новітніх технологій малий та середній бізнес. Пропонуємо дослідити аналогічні стратегіï, які вже застосовано в інших країнах світу, та адаптувати їх до реалій сучасної української економіки. Наприклад, Китай запустив масштабний план індустріальної політики під назвою «Китай 2025», щоби стати провідною у світі промисловою країною завдяки технологіям Індустрії 4.0. Саме цим планом передбачено такий вектор руху, як допомога відсталим регіонам, оскільки в Китаї, як відомо, є сильний контраст між провінціями. У зазначеному плані визначається, що інноваційні регіони повинні розвивати міжрегіональні зв'язки та залучати відсталі регіони до стратегічних цілей країни.

4) Популяризація можливостей та переваг технологічних інструментів Індустрії 4.0 у провідних інноваційних регіонах. Сьогодні на території України є регіони, в яких активно розвиваються цифрові технології, сфера IT. Такими регіонами є Київ, Харків, Львів, Дніпро та деякі інші. Проте, на жаль, про Індустрію 4.0 знає досить вузьке коло фахівців. У Європі, для порівняння, вже розроблено відповідну програму «Горизонт Свропа (2021-2027)». Ця програма буде діяти з 2021 по 2017 роки. Ї̈і метою є надання певного самоврядування регіонам. Вони самі можуть вибирати свої методи політики, але головним є дотримання пріоритетної мети, поставленої державою. Така стратегія $є$ особливо актуально для інноваційно розвинених регіонів, адже в них є підгрунтя для подальшого інноваційного зростання. Водночас вони вже сформували позитивний імідж перед державним урядом, отже, домоглися довіри для свого регіонального апарату.

5) Розроблення нової політики кіберзахисту персональних даних. В основі всіх новітніх технологій, покладених в основу Індустрії 4.0, лежить інформація. Це найважливіша цінність, яку має та матиме людство в майбутньому. Звісно, будуть кіберзлодії, які намагатимуться поцупити важливу інформацію чи персональні дані. Інформації ставатиме все більше, відповідно, потрібно створювати стратегії щодо покращення системи захисту інформації. Необхідні будуть зміни також у законодавчій базі, а саме встановлення конкретних правових меж. Це сприятиме зменшенню ризиків та витрат підприємств.

Висновки. Таким чином, оцінивши стан та готовність України до новітніх технологій Індустрії 4.0, можемо впевнено стверджувати, що Україна має достатній потенціал до розвитку цієї сфери. Кількість висококваліфікованих працівників, результати, які вони вже демонструють на міжнародній арені, є підтвердженнями цього висновку. Здійснені економіко-математичні розрахунки та побудова тренду з високим ступенем ймовірності свідчать про зростання кількості працівників, зайнятих у цій сфері, зростання обсягу виконання та експорту IКТ.

Задля активізації запровадження та ефективності використання інноваційних інструментів запропоновано вжити низку заходів на макро- та мікрорівнях, таких як розроблення стратегії регіонального розвитку промисловості; державна підтримка створення інноваційних осередків у вищих навчальних закладах; сприяння поширенню технологічних інновацій Індустрії 4.0 у відсталих регіонах; популяризація можливостей та переваг технологій Індустрії 4.0 у провідних інноваційних регіонах; розроблення нової політики кіберзахисту персональних даних.

Подальшого дослідження потребують можливості вирішення питання зайнятості населення, вплив новітніх технологій на навколишнє середовище.

\section{Список використаних джерел:}

1. Industry 4.0: Integration of the future. URL: http://energy/polis.ru/soderzhanie/2646/industriya/40/integraciya/buduschego.html (дата звернення: 05.02.19).

2. Lorenz M., Russmann M., Strack R., Lasse L.K., Bolle M. Man and Machine in Industry 4.0. How Will Technology Transform the Industrial Workforce Through 2025? URL: https:/www.bcgperspectives.com/content/articles/ technology/business/transformation/engineered/products/infrastructure/man/machine/industry/4/\#chapter1 (дата звернення: 15.02.19).

3. Schlaepfer R.C., Koch M., Merkofer P. Industry 4.0. Challenges and solutions for the digital transformation and use of exponential technologies. URL: http://www2.deloitte.com/content/dam/Deloitte/ch/Documents/manufacturing/ch/en/manufacturing/ industry/4/0/24102014.pdf (дата звернення: 05.03.19). 
4. Industry 4.0: The Future of Productivity and Growth in Manufacturing Industries / M. Russmann, M. Lorenz, P. Gerbert, M. Waldner, J. Justus, P. Engel, M. Harnisch. URL: https://www.bcgpers/pectives.com/content/articles/engineered_products_/ project_business_industry_40_future_productivity_/growth_manufacturing_industries (дата звернення: 09.03.19).

5. The site of Lapp Group. The Industry 4.0. The revolution in industrial. URL: http://content.lappgroup.com/fileadmin/ DAM/Lapp_Ukraine/Kabelniy_myr/UA_Kabel/welt_01_2015_small.pdf (дата звернення: 25.03.19).

6. Вишневский Ю. Как будет работать мировая экономика через 15 лет. Власть денег. 2015. № 9/434. URL: http:// www.dsnews.ua/future/kak/budet/rabotat/mirovaya/ekonomika/cherez/15/let/05092015132200 (дата звернення: 25.03.19).

7. Інформаційна довідка, підготовлена Європейським інформаційно-дослідницьким центром «ТТ-індустрія: тренди та прогнози розвитку». URL: http://euinfocenter.rada.gov.ua/uploads/documents/29337.pdf (дата звернення: 20.03.19).

8. Офіційний сайт Асоціації підприємств промислової автоматизації України. URL: https://appau.org.ua (дата звернення: 20.03.19).

9. Офіційний сайт платформи «Бізнес-партнерство заради майбутнього». URL: https://business.ua/business/4970ukraina-uviishla-do-kola-krain-lideriv-u-sferi-itautsorsynhu (дата звернення: 12.04.19).

10. Офіційний сайт платформи “Business Views”. URL: https://businessviews.com.ua/ru/business/id/grafik-dnja-kilkistprogramistiv-v-ukrajini-zrostaje-1911 (дата звернення: 12.04.19).

11. Рекомендации по реализации проекта «Индустрия 4.0». Резюме заключительного отчета рабочей группы «Индустрия 4.0». URL: http://internetofthings.ru/images/2015/2013_Industrie_40_Executive_Summary_russ_web.pdf (дата звернення: 05.04.19).

12. Річні звіти компанії “А.T. Kearney” за 2016-2018 роки. URL: https://www.kearney.com/digital-transformation/ gsli?utm_source=PRNewswire\&utm_medium=pr\&utm_term=DT\&utm_campaign=2019GSLI\&utm_content (дата 3вернення: $1 \overline{5} .04 .19)$.

13. Світлична В. Теоретичні базис нової парадигми суспільства - економіки знань. Економіка: реалї̈ часу. 2015. № 3 (19). C. 184-193.

14. Стефінович Д. Відкриття центру Індустрії 4.0 на базі КПІ ім. Ігоря Сікорського. Київський політехнік. № 16. С. 6.

15. Что такое Индустрия 4.0? Цифры и факты. URL: http://holzex.ru/chto/takoe/industriya/4/0/tsifryi/i/faktyi (дата звернення: 09.03.19).

\section{References:}

1. Industry 4.0: Integration of the future (2019), available at: http://energy/polis.ru/soderzhanie/2646/industriya/40/ integraciya/ buduschego.html (accessed: 5 February 2019).

2. Lorenz, M. Russmann, M. Strack, R. And Lasse Lueth, K. (2019), "Man and Machine in Industry 4.0. How Will Technology Transform the Industrial Workforce Through 2025?”, available at: https://www.bcgperspectives.com/content/ articles/technology/business/transformation/engineered/products/infrastructure/man/machine/industry/4/\#chapter1 (accessed: 15 February 2019).

3. Schlaepfer, R.C. Koch, M. and Merkofer, P. (2019), "Industry 4.0. Challenges and solutions for the digital transformation and use of exponential technologies", available at: http:/www2.deloitte.com/content/dam/Deloitte/ch/Documents/ manufacturing/ch/en/manufacturing/industry/4/0/24102014.pdf (accessed: 5 March 2019).

4. Russmann, M. Lorenz, M. Gerbert, P. and Waldner M. (2019), "Industry 4.0: The Future of Productivity and Growth in Manufacturing Industries", available at: https://www.bcgpers/pectives.com/content/articles/engineered_products_/project_ business_industry_40_future_productivity_/growth_manufacturing_industries (accessed: 9 March 2019).

5. The official site of Industry $\overline{4} .0$ project. The revolution in industrial enterprises (2015), available at: http://content.lappgroup.com/fileadmin/DAM/Lapp_Ukraine/Kabelniy_myr/UA_Kabel/welt_01_2015_small.pdf (accessed: 25 March 2019).

6. Vyshnevskyj, Yu. (2015), "How the global economy will work in 15 years", Vlast deneh, vol. 9, available at: http://www.dsnews.ua/future/kak/budet/rabotat/mirovaya/ekonomika/cherez/15/let/05092015132200 (accessed: 20 March 2019).

7. Information technology prepared by the European Information Technology Center IT-Industry: Trends and Predict Development (2017), available at: http://euinfocenter.rada.gov.ua/uploads/documents/29337.pdf (accessed: 20 March 2019).

8. Official site of the Association of Industrial Automation Enterprises of Ukraine (2019), available at: https://appau.org.ua (accessed: 20 March 2019).

9. The official site of the platform Business-partnership for the Future (2019), available at: https://business.ua/business/4970ukraina-uviishla-do-kola-krain-lideriv-u-sferi-itautsorsynhu (accessed: 12 April 2019).

10. The official site of the platform BusinessViews (2019), available at: https://businessviews.com.ua/ru/business/id/grafikdnja-kilkist-programistiv-v-ukrajini-zrostaje-1911 (accessed: 12 April 2019).

11. Recommendations for the implementation of the project Industry 4.0. Summary of the Final Report of the Industry 4.0 Working Group (2015), available at: http://internetofthings.ru/images/2015/2013_Industrie_40_Executive_Summary_russ_ web.pdf (accessed: 05 April 2019).

12. A.T. Kearney Annual Reports for 2016-2018 (2018), available at: https://www.kearney.com/digital-transformation/ gsli?utm_source=PRNewswire\&utm_medium =pr\&utm_term=DT\&utm_campaign=2019GSLI\&utm_content (accessed: 15 April 2019$)$.

13. Svitlychna, V. (2015), "Theoretical basis of a new paradigm of society - the knowledge economy", Ekonomika: realii chasu, vol. 3 (19), pp. 184-193.

14. Stefinovych, D. (2016), "Opening of Industry 4.0 Center based on Igor Sikorsky KPI”, Kyivskyj politekhnik, vol. 16 , p. 6.

15. What is Industry 4.0? Figures and facts (2019), available at: http://holzex.ru/chto/takoe/industriya/4/0/tsifryi/i/faktyi (accessed: 9 March 2019). 
Skorobogatova Natalia, Kravchuk Yuliia

National Technical University of Ukraine "Igor Sikorsky Kyiv Polytechnic Institute"

\section{UKRAINE'S READINESS FOR THE IMPLEMENTATION OF THE MODERN INDUSTRY 4.0 TECHNOLOGIES}

The article describes the essence and concepts of the latest trend of development of Industry 4.0 and identifies nine main directions of development of the Fourth Industrial Revolution. It is proved that the basis of Industry 4.0 is the information and communication technologies, the driving force of which is the IT sphere. The current state of development of the IT sphere in Ukraine is analyzed, the main factors influencing it and the predictive values are determined. Ukraine has been shown to have great potential in implementing the latest Industry 4.0 technologies. This is evidenced by the steady growth in exports of IT products, as well as the steady increase in the number of highly skilled workers. Ukraine's place in the Global Services Location Index has been identified and a trend has been identified - in recent years, the country's position has improved due to the large number of highly skilled workers available, as well as a favorable business environment. Based on the research, it was concluded that Ukraine has a high potential in the development and implementation of the latest Industry 4.0 technologies. Practical recommendations are given on the next steps for Ukraine's effective entry into the world of Industry 4.0 innovators. In particular, the necessity of realization of the following measures is defined: development of a strategy of regional development of industry taking into account available resources and potential of development of international competitiveness; state support for the creation of appropriate innovation centers in higher education institutions; promoting the diffusion of technological innovation in Industry 4.0 in depressed regions; promoting the opportunities and benefits of Industry 4.0 technology in leading innovative regions; development of a new cybersecurity policy for personal data, etc. We believe that the implementation of the proposed measures will increase the competitiveness of domestic business and the economy as a whole. The practical implementation of the proposed measures requires a systematic approach to solving the problem at the macro and micro levels.

Key words: modern technologies, innovative development, Industry 4.0, information and communication technologies, international competitiveness.

JEL classification: L50, O14. 